\title{
Seroprevalence of Peste Des Petits Ruminants Virus from Samples Collected in Different Regions of Tanzania in 2013 and 2015
}

Tebogo Kgotlele ${ }^{1,2 *}$, Emeli Torsson ${ }^{1,3}$, Christopher Jacob Kasanga ${ }^{1}$, Jonas Johansson Wensman ${ }^{1,4}$ and Gerald Misinzo ${ }^{1}$

${ }^{1}$ Department of Veterinary Microbiology and Parasitology, Sokoine University of Agriculture, Chuo Kikuu, Morogoro, Tanzania

${ }^{2}$ Molecular Biology Section, Botswana National Veterinary Laboratory, Gaborone, Botswana

${ }^{3}$ Department of Biomedical Sciences and Veterinary Public Health, Swedish University of Agricultural Sciences, SE-750 07 Uppsala, Sweden

${ }^{4}$ Department of Clinical Sciences, Swedish University of Agricultural Sciences, SE-750 07 Uppsala, Sweden

\begin{abstract}
Sero-surveillance was conducted to determine seroprevalence of peste des petits ruminant's virus (PPRV) in sheep and goats population of Tanzania using samples collected in 2013 and 2015. A total of 3,838 samples were collected from villages in 14 of the 25 mainland regions. Samples were tested by competitive ELISA for detection of antibodies against PPRV. Overall, 998 of the samples were found to be positive for antibodies against PPR, giving a seroprevalence of $27.1 \%$. In this study, there was no statistical significant difference of getting PPR between sheep and goats (odds ratio of $1.06,95 \% \mathrm{Cl} 0.89-1.25$ ). The overall seroprevalence indicates that PPR is prevalent in small ruminants in the study areas. The study also confirms the presence of antibodies against PPR in sheep and goats in regions of Tanzania that previously had little to no data on the disease, an indication that PPR is spreading within Tanzania with the possibility of spreading to neighboring countries.
\end{abstract}

Keywords: Peste des petits ruminants; Seroprevalence; cELISA; Tanzania

\section{Introduction}

Peste des petits ruminants (PPR) is a highly contagious viral disease of goats and sheep characterized by oculo-nasal discharges, stomatitis, diarrhea and pneumonia [1]. It is a disease of economic significance because of its transboundary nature, high morbidity and mortality rates which result in loss of production, limitations on export and threat to human food chain [2]. The disease is caused by peste des petits ruminants virus (PPRV), belonging to the genus Morbillivirus of the family Paramyxoviridae. The virus is highly contagious and easily transmitted by direct contact through secretions and/or excretions of infected animals [3].

Peste des petits ruminants was first reported in West Africa in the early 1940s and later recognized as endemic in both West and Central Africa $[4,5]$. Currently, PPR is present in Central, Eastern and Western Africa, Asia, and the Near and Middle East [6]. In East Africa, PPR was detected serologically in Kenya and Uganda in 2007 [7].

Efforts to determine presence of PPR in sheep and goats in Tanzania can be traced back to Loliondo in 1995 through grey literature [8]. Three years later in 1998, the presence of antibodies against PPR was ruled out by a comprehensive study that did not find any antibodies against PPR in Tanzania sheep and goats [9]. A retrospective study done in Ngorongoro district using samples collected for Rift Valley fever virus and PPR surveys showed presence of antibodies against PPR in samples collected in 2004, suggesting the presence of PPRV at that period [8].

PPR was officially confirmed in Tanzania in 2008 and it was confined to the northern zone in districts bordering Kenya [10,11]. This follows the official confirmation of PPR in neighboring Kenya in 2007 [7]. The possible spread from Kenya to Tanzania may have been due to the difficulty in controlling transnational livestock movements across borders, especially where Maasai pastoralists are found on either side [12]. In 2011, an outbreak of PPR was reported in southern Tanzania [13]. In other areas of Tanzania, limited to no data is available about the disease. Therefore, the objective of this study was to determine seroprevalence of PPR in selected regions of Tanzania to have a current comprehensive view about the distribution of PPR in the country.

\section{Materials and Methods}

\section{Samples}

A total of 3,838 serum samples from 118 villages collected from sheep and goats in 14 regions of Tanzania (Figure 1) in 2013 and 2015 were used (Table 1). Samples were collected from apparently healthy animals, that is did not show any clinical signs associated with PPR. These serum samples were submitted to Sokoine University of Agriculture for official confirmation of PPR in Tanzania before a PPR vaccination campaign. Unfortunately, sex of sampled animals could not be retrieved from information stated in the submission forms.

\section{Detection of PPR antibodies using competitive enzyme linked immunosorbent assay (cELISA)}

Sera were tested for antibodies against PPRV using a competitive ELISA kit (cELISA) (CIRAD EMVT, Montpellier, France). The test was performed according to manufacturer's instructions. Samples presenting a competition percentage of less than or equal to $50 \%$ were considered positive for PPRV antibodies.

\section{Statistical analysis}

Apparent prevalence estimates were used to estimate true prevalence [14] and the kit's relative diagnostic sensitivity and specificity of $92.2 \%$ and $98.9 \%$ respectively [15]. The odds ratio was calculated to assess the association between being seropositive for PPR and animal species [16].

*Corresponding author: Tebogo Kgotlele, Department of Veterinary Microbiology and Parasitology, Sokoine University of Agriculture, PO Box 3019, Chuo Kikuu, Morogoro, Tanzania, Tel: +26771879071/ +255768822648 E-mail: tkgotlele@gmail.com

Received September 26, 2016; Accepted October 21, 2016; Published October 26, 2016

Citation: Kgotlele T, Torsson E, Kasanga CJ, Wensman JJ, Misinzo G (2016) Seroprevalence of Peste Des Petits Ruminants Virus from Samples Collected in Different Regions of Tanzania in 2013 and 2015. J Vet Sci Technol 7: 394. doi: 10.4172/2157-7579.1000394

Copyright: @ 2016 Kgotlele T, et al. This is an open-access article distributed under the terms of the Creative Commons Attribution License, which permits unrestricted use, distribution, and reproduction in any medium, provided the original author and source are credited. 
Citation: Kgotlele T, Torsson E, Kasanga CJ, Wensman JJ, Misinzo G (2016) Seroprevalence of Peste Des Petits Ruminants Virus from Samples Collected in Different Regions of Tanzania in 2013 and 2015. J Vet Sci Technol 7: 394. doi: 10.4172/2157-7579.1000394

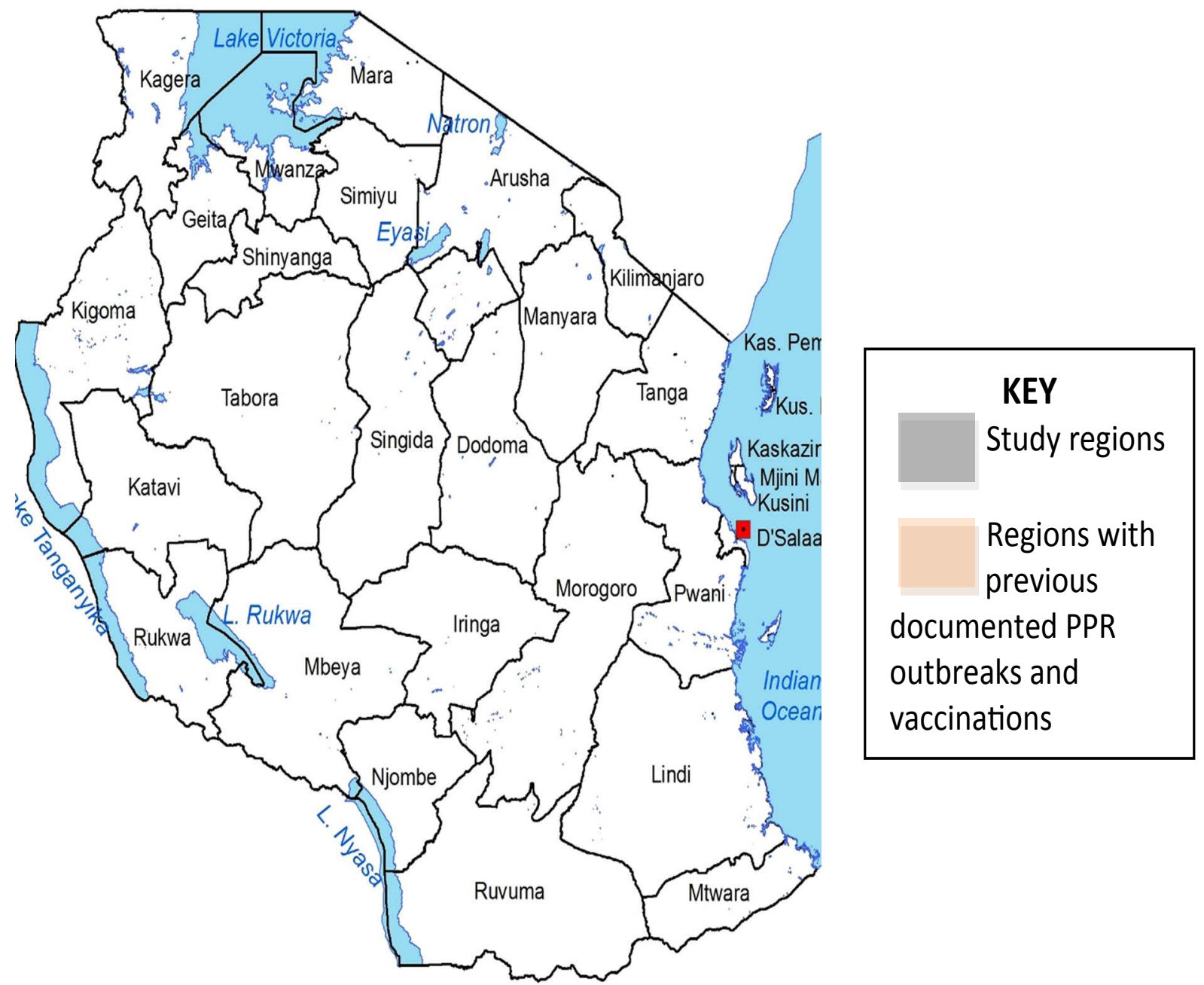

Figure 1: Map of Tanzania showing study regions in colour (except Mtwara).

\begin{tabular}{|c|c|c|c|c|c|c|c|c|c|c|}
\hline \multirow{2}{*}{ Region } & \multirow{2}{*}{$\begin{array}{l}\text { Districts } \\
\text { (Villages) }\end{array}$} & \multicolumn{3}{|c|}{ Goats } & \multicolumn{3}{|c|}{ Sheep } & \multicolumn{3}{|c|}{ Total } \\
\hline & & Total & Positive (\%) & TP $(95 \% \mathrm{Cl})$ & Total & Positive (\%) & TP $(95 \% \mathrm{Cl})$ & Total & Positive (\%) & TP $(95 \% \mathrm{Cl})$ \\
\hline Morogoro & $2(10)$ & 178 & $124(69.7)$ & $73.5(66.4-81.7)$ & 38 & $25(65.8)$ & $69.4(53.4-85.5)$ & 216 & $149(70.0)$ & $72.8(66.3-79.4)$ \\
\hline Shinyanga & $3(4)$ & 217 & $16(7.4)$ & $7.2(3.5-10.9)$ & 33 & $0(0)$ & $<0$ & 250 & $16(6.4)$ & $6.2(2.9-9.4)$ \\
\hline Coastal & $3(14)$ & 310 & $90(29.0)$ & $30.3(24.9-35.7)$ & 41 & $13(31.7)$ & $33.1(18-48.3)$ & 351 & $103(29.3)$ & $30.6(25.5-35.7)$ \\
\hline Simiyu & $3(7)$ & 202 & $15(7.4)$ & $7.3(3.4-11.1)$ & 59 & $6(10.2)$ & $10.2(2-18.4)$ & 261 & $21(8.1)$ & $7.9(4.4-11.4)$ \\
\hline Kagera & $3(16)$ & 198 & $6(3.0)$ & $2.6(0-5.1)$ & 12 & $0(0)$ & $<0$ & 210 & $6(2.9)$ & $2.4(0-4.8)$ \\
\hline Mwanza & $7(23)$ & 414 & $15(3.6)$ & $3.2(1.3-5.1)$ & 92 & $0(0)$ & $<0$ & 506 & $15(3.0)$ & $2.5(0.9-4.1)$ \\
\hline Kilimanjaro & $1(5)$ & 80 & $29(36.3)$ & $38(26.7-49.2)$ & 66 & $12(18.2)$ & $18.7(8.8-28.6)$ & 146 & $41(28.1)$ & $29.3(21.5-37)$ \\
\hline Manyara & $1(5)$ & 92 & $67(72.8)$ & $76.9(67.2$ - 86.6) & 55 & $30(54.5)$ & $57.4(43.4-71.5)$ & 147 & $97(66.0)$ & $69.6(61.5-77.8)$ \\
\hline Arusha & $1(5)$ & 97 & $66(68.0)$ & $71.8(61.8-81.7)$ & 56 & $37(66.1)$ & $69.7(56.5$ - 82.9) & 153 & $103(67.3)$ & $71.1(63.1$ - 79) \\
\hline Dodoma & $3(12)$ & 420 & $240(57.1)$ & $60.2(55.2-65.3)$ & 180 & $104(57.8)$ & $60.9(53.2-68.6)$ & 600 & $344(57.3)$ & $60.4(56.2-64.6)$ \\
\hline Singida & $2(8)$ & 167 & $39(23.4)$ & $24.2(17.4-31.1)$ & 79 & $0(0)$ & $<0$ & 246 & 39 (15.9) & $16.2(11.4-21.1)$ \\
\hline Tabora & $3(3)$ & 245 & $31(12.7)$ & $12.8(8.4-17.3)$ & 115 & $11(9.6)$ & $9.5(3.8-15.3)$ & 360 & $41(11.4)$ & $11.5(8-15$ \\
\hline Katavi & $3(3)$ & 130 & $5(3.8)$ & $3.5(-0.1-7)$ & 62 & $0(0)$ & $<0$ & 192 & $5(2.6)$ & $2.1(-0.3-4.5)$ \\
\hline Kigoma & $3(3)$ & 136 & $16(11.8)$ & $11.9(6.1-17.7)$ & 64 & $2(3.1)$ & $2.7(-1.9-7.2)$ & 200 & $18(9.0)$ & $8.9(4.7-13.2)$ \\
\hline Total & 38 (118) & 2886 & $759(26.3)$ & $27.4(25.7-29.1)$ & 952 & $240(25.2)$ & $26.2(23.3-29.1)$ & 3838 & $998(26.0)$ & $27.1(25.6-28.5)$ \\
\hline
\end{tabular}

Total: total number of animals sampled, Positive: number of animals tested positive with percentage given in parenthesis, TP: true prevalence with $95 \%$ confidence interval in parenthesis.

Table 1: Regions where serum samples from sheep and goats were collected in Tanzania. 
Citation: Kgotlele T, Torsson E, Kasanga CJ, Wensman JJ, Misinzo G (2016) Seroprevalence of Peste Des Petits Ruminants Virus from Samples Collected in Different Regions of Tanzania in 2013 and 2015. J Vet Sci Technol 7: 394. doi: 10.4172/2157-7579.1000394

Page 3 of 5

\section{Results}

From 3,838 serum samples tested, $998(26.0 \%)$ were positive; 759 (26.3\%) of 2886 from goats and $240(25.2 \%)$ of 952 from sheep were positive (Table 2 and Figure 2). Overall true seroprevalence was $27.1 \%$ (95\% CI, 25.6-28.5) and seroprevalence for goats and sheep was $27.4 \%$ (95\% CI, 25.7-29.1) and 26.2\% (95\% CI, 23.3-29.1), respectively. Morogoro region had the highest overall seroprevalence $(72.8 \%, 66.3-$ 79.4) of antibodies against PPRV while Katavi region had the lowest (2.1\%, -0.3-4.5). The odds of being seropositive to PPR was 1.06 (95\% CI 0.89-1.25) times higher in goats compared to sheep, a figure that is not statistically significant (Table 3).

\section{Discussion}

This study shows that PPR was widely prevalent in small ruminants in the study areas. All regions had seropositive cases. The overall observed seroprevalence $(27.1 \%, 25.6-28.5)$ (Table 2) is low compared to previous reports from northern and southern Tanzania performed in 2009 at $45.4 \%$ [11] and 2012 at $31.0 \%$ [13] respectively. There is a statistical significance $(\mathrm{p}<0.05)$ between the studies and years. This difference may be attributed to vaccination campaigns (Figure 1). Though the seroprevalence is low, the figure is highly significant in a country with an estimated population of sheep around 8 million and goats around 16.7 million [17].

Though some regions registered seroprevalence of less than 20\% (Figure 2), this indicates that PPR is widely prevalent in small ruminants in areas where the study was conducted. Data from studies in west, east and central Africa indicate that PPRV antibodies can be widespread among goats and sheep flocks raised in the tropics $[9,3,18,19]$. Studies also indicate cELISA as a preferred diagnostic test for screening antibodies against the PPRV. This is because the test is simple, rapid, specific and sensitive for intensive surveillance [20]. Screening for antibodies against PPRV in different geographical areas of a country with varying climatic conditions has been helpful in developing disease control strategies [21]. Hence these results can be helpful to government officials in developing control strategies for Tanzania.

The seropositivity difference between sheep and goats remains unclear in literature. In this study, prevalence between the two species was sheep $26.2 \%$ and goats $27.4 \%$. The odds of being seropositive were 1.06 (95\% CI 0.89-1.25) in goats than in sheep, which implies there is no difference between the species. This is in contradiction with some studies, including one carried out in Tanzania [11], which reported a

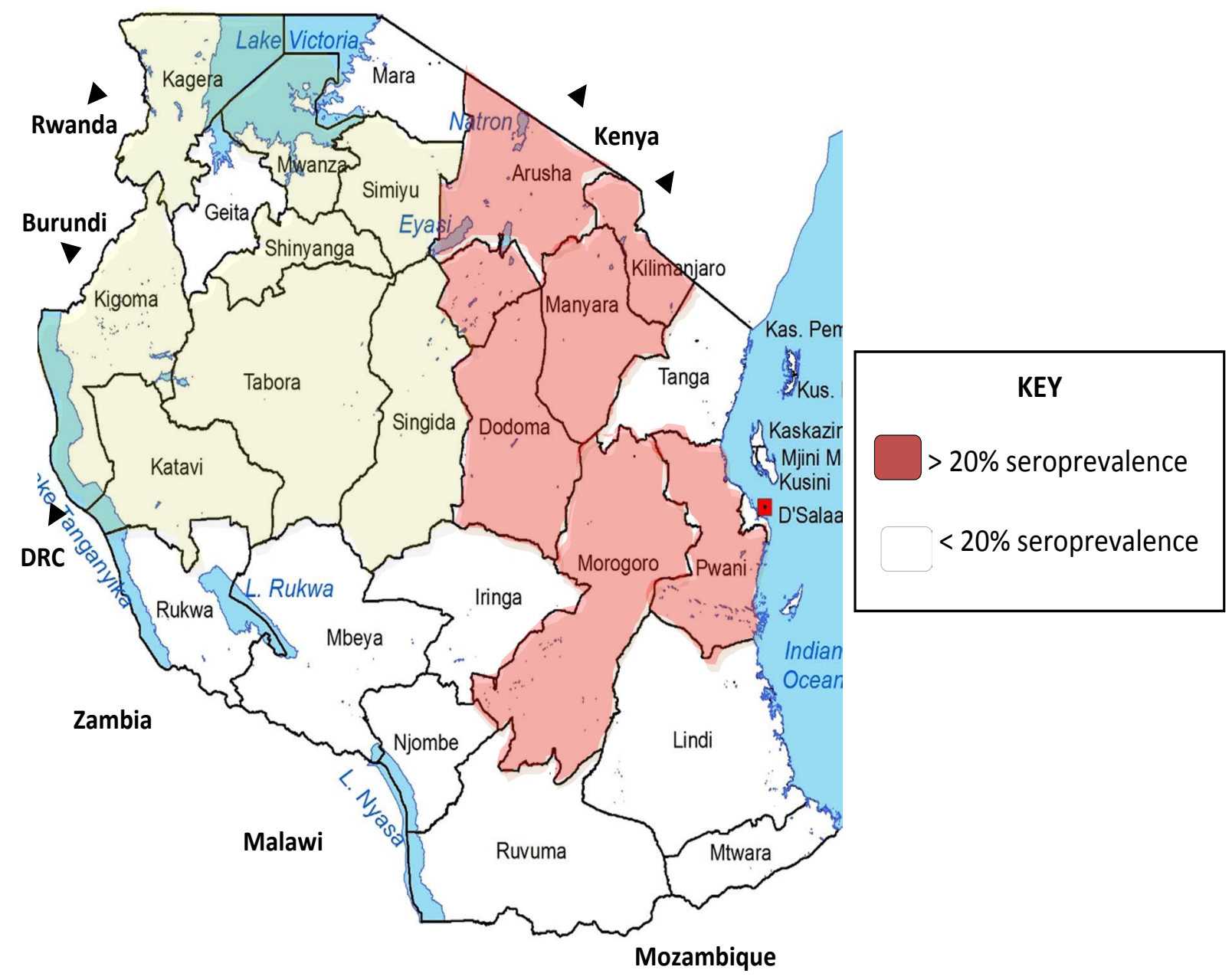

Figure 2: Map of Tanzania showing seroprevalences of study regions. 
Citation: Kgotlele T, Torsson E, Kasanga CJ, Wensman JJ, Misinzo G (2016) Seroprevalence of Peste Des Petits Ruminants Virus from Samples Collected in Different Regions of Tanzania in 2013 and 2015. J Vet Sci Technol 7: 394. doi: 10.4172/2157-7579.1000394

Page 4 of 5

\begin{tabular}{|c|c|c|c|c|}
\hline Region & Year collected & Sheep & Goats & Total \\
\hline Morogoro & 2013 & 38 & 178 & 216 \\
\hline Shinyanga & 2013 & 33 & 217 & 250 \\
\hline Coastal & 2013 & 41 & 310 & 351 \\
\hline Simiyu & 2013 & 59 & 202 & 261 \\
\hline Kagera & 2013 & 12 & 198 & 210 \\
\hline Mwanza & 2013 & 92 & 414 & 506 \\
\hline Kilimanjaro & 2015 & 66 & 80 & 146 \\
\hline Manyara & 2015 & 55 & 92 & 147 \\
\hline Arusha & 2015 & 56 & 97 & 153 \\
\hline Dodoma & 2013 & 180 & 420 & 600 \\
\hline Singida & 2013 & 79 & 167 & 246 \\
\hline Tabora & 2013 & 115 & 245 & 360 \\
\hline Katavi & 2013 & 62 & 130 & 192 \\
\hline Kigoma & 2013 & 64 & 136 & 200 \\
\hline \multicolumn{2}{|c|}{ Total } & 952 & 2886 & 3838 \\
\hline
\end{tabular}

Table 2: Regional seroprevalence of antibodies against PPRV in goats and sheep in Tanzania.

\begin{tabular}{|c|c|c|c|}
\hline Variable & Odds ratio & $\mathbf{9 5 \%} \mathbf{C l}$ & P value \\
\hline Species (goats vs sheep) & 1.06 & $0.89-1.25$ & 0.507 \\
\hline
\end{tabular}

Table 3: Association of species and being seropositive for PPR.

higher seroprevalence in goats than in sheep and linked it to higher fecundity in goats compared to sheep $[2,18,22]$. Other studies have reported higher seroprevalence in sheep than goats, attributing it to lower number of sheep sampled or due to the fact that goats are often affected more severely by the disease hence die prior to sampling $[19,23]$. Therefore, more investigations are needed to further determine the variation between the species.

In 2008 and 2010, PPR vaccination was carried out around the 2008 outbreak foci (Arusha region) with another vaccination ring in Morogoro and Mtwara regions, shown in Figure 1 [24]. Arusha and Mtwara regions were chosen because they had already been seen as hotspot areas while Morogoro region acted as a buffer zone for spread of the disease from south (Mtwara region) to north. The use of antibiotics in managing clinical cases is also believed to increase survival rate of sick animals [8] thus the surviving animals will carry antibodies against PPRV. These two factors may have contributed to the high seroprevalence because cELISA cannot discriminate from previously PPRV infected animals and vaccinated animals. Small ruminants vaccinated on a large scale with PPR vaccines will still test positive for antibodies against PPRV [25]. Despite this, presence of antibodies against PPR in regions that previously were thought to be free and no vaccinations have been performed, such as Mwanza, Shinyanga, Kigoma and Tabora, indicates that the disease is spreading (Figure 2). The data means future vaccinations should cover all regions of the country and not concentrate in known high risk areas. Small ruminants are easily moved especially for sale in markets. Live animal markets are an important vehicle for transmission of infectious diseases [25]. This was demonstrated in a study [13] that found out that lack of appropriate veterinary services and inadequate infrastructure especially in the local animal markets in Tanzania may be facilitating transmission of PPR. Trade also brings about livestock theft that has been found to play a major role in maintaining transmission of infectious diseases in many areas of East Africa [19].

In conclusion, this study has confirmed the presence of PPR in regions of Tanzania that previously had little to no data on the disease. This is a step forward to getting information about the disease situation that can help to properly put into place systems and proper control

measures to improve animal welfare and reduce episodes of disease outbreaks.

\section{Acknowledgements}

We would like to thank the Ministry of Livestock and Fisheries Development (MLFD) and District Veterinary Officers for sera collection. We also thank Miriam Richard Makange, Clara Yona and Margot Coudijzer for their help during sample analysis. The author is sponsored by a grant from the Wellcome Trust to the Southern African Centre for Infectious Disease Surveillance, SACIDS (grant WT087546MA), Swedish Research Council (grant nos. 348-2013-6402 and 348-2014-4293) and Sokoine University of Agriculture. The opinions expressed herein are those of the authors and do not necessarily reflect the view of Sokoine University of Agriculture.

\section{Conflict of Interest Statement}

The authors declare that there is no conflict of interests regarding the publication of this article.

\section{References}

1. Abubakar M, Rasool MH, Manzoor S, Saqalein M, Rizwan M, et al. (2016) Evaluation of Risk Factors for Peste des Petits Ruminants Virus in Sheep and Goats at the Wildlife-Livestock Interface in Punjab Province, Pakistan. BioMed Res Int 2016: 7826245 .

2. Zahur AB, Ullah A, Hussain M, Irshad H, Hameed A, et al. (2011) Seroepidemiology of peste des petits ruminants (PPR) in Pakistan. Prevent Vet Med 102: 87-92

3. Banyard AC, Parida S, Batten C, Oura C, Kwiatek O, et al. (2010) Globa distribution of peste des petits ruminants virus and prospects for improved diagnosis and control. J Gen Virol 91: 2885-2897.

4. Gargadennec L, Lalanne A (1942) La peste des petits ruminants. Bull Serv Zoo AOF 5: 15-21.

5. Abraham G, Sintayehu A, Libeau G, Albina E, Roger F, et al. (2005) Antibody seroprevalences against peste des petits ruminants (PPR) virus in camels, cattle, goats and sheep in Ethiopia. Prevent Vet Med 70: 51-57.

6. Libeau G, Diallo A, Parida S (2014) Evolutionary genetics underlying the spread of peste des petits ruminants virus. Anim Front 4: 14-20.

7. Karimuribo ED, Loomu PM, Mellau LSB, Swai ES (2011) Retrospective study on sero-epidemiology of peste des petits ruminants before its official confirmation in northern Tanzania in 2008. Res Opin Anim Vet Sci 1: 184-187.

8. Wambura PN (2000) Serological evidence of the absence of peste des petits ruminants in Tanzania. Vet Rec 146: 473-474.

9. Kivaria FM, Kwiatek O, Kapaga AM, Geneviève L, Mpelumbe-Ngeleja CAR, et al. (2009) Serological and virological investigations on an emerging Peste des Petits Ruminants Virus infection in sheep and goats in Tanzania. Proceedings of the 27th Tanzania Veterinary Association Scientific Conference.

10. Swai ES, Kapaga A, Kivaria F, Tinuga D, Joshua G, et al. (2009) Prevalence and distribution of Peste des petits ruminants virus antibodies in various districts of Tanzania. Vet Res Commun 33: 927-936.

11. Kivaria FM, Kwiatek O, Kapaga AM, Swai ES, Libeau G, et al. (2013) The incursion, persistence and spread of peste des petits ruminants in Tanzania: Epidemiological patterns and predictions. Onderstepoort J Vet Res 80: 01-10.

12. Muse EA, Karimuribo ED, Gitao GC, Misinzo G, Mellau LS, et al. (2012) Epidemiological investigation into the introduction and factors for spread of Peste des Petits Ruminants, southern Tanzania. Onderstepoort J Vet Res 79: 49-54.

13. Rogan WJ, Gladen B (1978) Estimating prevalence from the results of a screening test. Am J Epidemiol 107: 71-76.

14. Libeau G, Prehaud C, Lancelot R, Colas F, Guerre L, et al. (1995) Development of a competitive ELISA for detecting antibodies to the peste des petits ruminants virus using a recombinant nucleobrotein. Res Vet Sci 58: 50-55.

15. Altman DG (1991) Practical statistics for medical research, Chapman and Hall, London.

16. http://www.mifugouvuvi.go.tz/wp-content/uploads/2015/10/TLMI-electronic.pdf

17. Abdalla AS, Majok AA, El Malik KH, Ali AS (2012) Sero-prevalence of peste des petits ruminants virus (PPRV) in small ruminants in Blue Nile, Gadaref and North Kordofan States of Sudan. J Public Health Epidemiol 4: 59-64. 
Citation: Kgotlele T, Torsson E, Kasanga CJ, Wensman JJ, Misinzo G (2016) Seroprevalence of Peste Des Petits Ruminants Virus from Samples Collected in Different Regions of Tanzania in 2013 and 2015. J Vet Sci Technol 7: 394. doi: 10.4172/2157-7579.1000394

18. Megersa B, Biffa D, Belina T, Debela E, Regassa A, et al. (2011) Serological investigation of Peste des Petits Ruminants (PPR) in small ruminants managed under pastoral and agro-pastoral systems in Ethiopia. Small Rumin Res 97: 134-138.

19. Singh RP, Sreenivasa BP, Dhar P, Shah LC, Bandyopadhyay SK (2004) Development of a monoclonal antibody based competitive-ELISA for detection and titration of antibodies to peste des petits ruminants (PPR) virus. Vet Microbiol 98: 3-15.

20. Balamurugan V, Saravanan P, Sen A, Rajak KK, Bhanuprakash V, et al. (2011) Sero-epidemiological study of peste des petits ruminants in sheep and goats in India between 2003 and 2009. Rev Sci Tech 30: 889-896.

21. Rashid A, Asim M, Hussain A (2008) Seroprevalence of peste des petits ruminants (PPR) virus in goats, sheep and cattle at livestock production research institute Bahadurnagar Okara. J Anim Plant Sci 18: 114-116.
22. Khan HA Siddique M, Arshad MJ, Khan QM, Rehman SU (2007) Seroprevalence of peste des petits ruminants (PPR) virus in sheep and goats in Punjab province of Pakistan. Pakistan Vet J 27: 109-112.

23. Ministry of Livestock and Fisheries Development (2013) Peste des petits ruminants (PPR) progressive control and eradication strategy. The United Republic of Tanzania.

24. Libeau G (2015) Current Advances in Serological Diagnosis of Peste des Petits Ruminants Virus. In: Peste des Petits Ruminants Virus. Springer Berlin Heidelberg, Pp: 133-154.

25. Domenech J, Lubroth J, Eddi C, Martin V, Roger F (2006) Regional and international approaches on prevention and control of animal transboundary and emerging diseases. Ann NY Acad Sci 1081: 90-107. 